\title{
Personalized Learning as A Method of Moral and Intellectual Development in The Humanitarization of the Post-Industrial Society
}

\section{El aprendizaje personalizado como método de desarrollo moral e intelectual en la humanización de la sociedad postindustrial}

\author{
Sergey Vladimirovich Kondratiev* \\ Moscow State University of Technology and Management named after K.G. Razumovsky (First \\ Cossack University), Moscow, Russia. \\ ORCID: https://orcid.org/0000-0002-8625-4460 \\ Natalya Georgievna Pavlova \\ Peoples' Friendship University of Russia (RUDN University), Moscow, Russia. \\ ORCID: https://orcid.org/0000-0002-1024-4936
}

\section{Nadezhda Rodionova}

Moscow State University of Technology and Management named after K.G. Razumovsky (First

Cossack University), Moscow, Russia.

ORCID: https://orcid.org/0000-0002-6118-4662

\section{Vladimir Ostroukhov}

Moscow State University of Technology and Management named after K.G. Razumovsky (First

Cossack University), Moscow, Russia.

ORCID: https://orcid.org/0000-0002-7949-8758

\section{Vladimir Sergeevich Bereznyakovskiy}

Moscow State University of Technology and Management named after K.G. Razumovsky (First

Cossack University), Moscow, Russia.

ORCID: https://orcid.org/0000-0002-0890-1036

Received 02-12-20 Revised 03-13-20 Accepted 07-13-20 On line 08-29-20

*Correspondence

Email: kondratiev.s.v@bk.ru
Cite as:

Kondratiev, S.V., Pavlova, N.G., Rodionova, N. Ostroukhov, V., \& Bereznyakovskiy, V.S. (2020). Personalized Learning as A Method of Moral and Intellectual Development in The Humanitarization of the Post-Industrial Society. Propósitos y Representaciones, 8 (SPE2), e679. Doi: http://dx.doi.org/10.20511/pyr2020.v8nSPE2.679 


\section{Summary}

The article presents the post-industrial society problem in the context of personal self-existence of the individual. A spiritually oriented humanitarian paradigm in the intellectual and moral development of the individual in the framework of solving the post-industrial society problems is identified. Personalized learning is considered as a special learning type focused on the personal and intellectual development of the individual on the way from egocentrism to altruism. Intellectual development in the framework of metacognitive learning strategies is presented. The spiritual and moral development of students is defined as personal reflection development. The article presents the empirical study data on the moral orientation of students' personality in educational organizations.

Keywords: Post-Industrial Society; Liberalism, Humanitarian Paradigm; Personalized Learning; Metacognitive Intellectual Representations; Competence; Skill; Spiritual and Moral Development; Reflection; Levels and Forms of Personality Development.

\section{Resumen}

El artículo presenta el problema de la sociedad postindustrial en el contexto de la autoexistencia personal del individuo. Se identifica un paradigma humanitario de orientación espiritual en el desarrollo intelectual y moral del individuo en el marco de la resolución de los problemas de la sociedad postindustrial. El aprendizaje personalizado se considera un tipo de aprendizaje especial centrado en el desarrollo personal e intelectual del individuo en el camino del egocentrismo al altruismo. Se presenta el desarrollo intelectual en el marco de las estrategias de aprendizaje metacognitivo. El desarrollo espiritual y moral de los estudiantes se define como el desarrollo de la reflexión personal. El artículo presenta los datos del estudio empírico sobre la orientación moral de la personalidad de los estudiantes en las organizaciones educativas.

Palabras clave: Sociedad postindustrial; Liberalismo; Paradigma humanitario; Aprendizaje personalizado; Representaciones intelectuales metacognitivas; Competencia; habilidad, desarrollo espiritual y moral; reflexión; Niveles y formas de desarrollo de la personalidad.

\section{Introduction}

In philosophy and social and humanitarian sciences in the last decades of the 20th century and especially at present, the human community is considered as post-industrial. The theoretical and methodological basis is the philosophical, sociological, socio-psychological and futurological developments of Daniel Bell, Alvin Toffler, Jean Furastier, Robert Heilbronerom, Peter Draker, V. L. Inozemtsev, etc. Post-industrial society is a society whose economy is the result of the technological revolution and substantial income growth. The priority has switched from primary goods production to services production. Information has become a production resource. Scientific developments has become the main driving force of the economy. According to postindustrialism theorists, society passes through three development stages: pre-industrial (agricultural), industrial and post-industrial (information), which are connected, according to Toffler, respectively with the matter, energy and information as the main resources and production results (Toffler, 1980). According to Bell, pre-industrial society was primarily mining and industrial - producing while post-industrial society is processing (Bell, 1976).

According to post-industrial society theorists, it obeys the convergence law. In this case, the contradictions between the "capitalist" and "socialist" forms of social existence are erased, and an integrative form of the economy with its ownership system and productive forces and relations of production arises. 
It should be noted that modern post-industrial society is characterized not only by a high level of scientific and technological progress and the dynamics of information in all human life spheres but also by the ambivalence of existential values, expressed in contradictions between public and individual morality. The result of such contradictions is, on the one hand, the consumption ideology. In this case, the personal self-existence value is determined by the ability to adapt to changes in social conditions, when a person reaches maximum material well-being. Personal self-realization is manifested in the virtualization of self-existence and creativity is focused on mass consumption. On the other hand, it is loneliness, egocentricity, contradictions between the individual orientation of personal self-realization and "being like everyone else", escape from reality, the desire for mysticism, etc. As a result, there are social crises, environmental disasters and many other things that put humanity on the verge of survival. All this requires a change in the ideological foundations of society's existence and the allocation of spiritual values rather than material ones as support in personal self-existence. The latter is reflected in the humanitarian, cultural, pedagogical and psychological paradigms. At the same time, religious philosophy and theology (including Christian) are often the basis. Thus, there are cultural, pedagogical and psychological concepts of V. V. Abramtseva, M. Yu. Baydakov, V. B. Bezgin, B. S. Bratusya, A. A. Bronzova, Ilarion (Alfeev), Zh.Larche, P. Y. Malkova, J. Mariten, E. Munier, A. I. Osipova, Platon (Igumnov), N. E. Pestova, etc. In all these concepts, the goal is to create a new person who can take responsibility for everything that happens in the world. This makes the humanitarianization of post-industrial society relevant.

In the conditions of humanitarianization of post-industrial society, the spiritual and moral development of the individual on the way from egocentrism to altruism and the formation of transcendent reflection become an imperative (Gostev, 2007; Zenkovsky, 1993; Karpikov, Kondratev, 2017; Slobodchikov, Isaev, 1995). The latter changes the priorities in the education systems and the younger generation upbringing. In the first place, the typical and individual in training and education reflected in the goals, content and organization of the process. On the other hand, the priority in the education system is the intellectual development of students. The latter is reflected in the concepts of developing, including personality-centred, personality-oriented, inclusive and other education (Davydov, 1986; Davydov, 1996; Rogers, 1969; Staroverova, Kovalev, Zaharova, 2014). However, most of these concepts focus on learning. Other intellectual abilities (convergence, creativity) are given secondary importance, although many students' learning ability is not the dominant ability. Along with this, it should be noted that developing learning, for the most part, is reduced to cognitive development indicators and is not focused on metacognitive structures in the individual intelligence of students. At the same time, metacognitions become particularly important in the context of information saturation. The interaction process between the subject and the object is not based on the principle of memorization and preservation, but the information management principle. Successful adaptation in the modern world and creative human activity both require the ability to manage the information flow.

All of the above makes personification (a person as a product of social development) and personalization (personality) of the educational environment of schools and professional education organizations relevant. In the first case, there is an orientation to both the conscious and the unconscious. In the second case, we refer to the influence on consciousness, i.e. individual development. Therefore, personification is focused not only on the personality but also on prepersonal formations. The latter is represented in personification as the development of a social individual as a social unconscious subject (Kondratiev, 2010: 19-20). Thus, the education personification involves focusing not only on the individual but also on typical, typological features of students and teachers. There should be a special training type aimed at the transition from cognitive to metacognitive strategies in the intellectual development of students and the spiritual and moral development of the individual from egocentrism to altruism. Such training should be called personalized. 


\section{Methods}

Analysis of scientific-psychological, scientific-pedagogical, philosophical, journalism and internet sources, generalization and systematization of theoretically and empirically obtained data. As a diagnostic tool, an original method was used - the projective test "Skazka Petushok" ["Fairytale Cockerel"], aimed at determining the levels and forms of personality development.

\section{Results and discussion}

In modern psychology, personification and personalization are often treated identically. This is largely due to the fact that personality is defined as the main ontogenetic "acquisition" of a person. At the same time, its structure includes, among other things, individual features. In the end, talking about personalization, it can be presented, with a certain conditionality degree, in the form of a cognitive, experiential and personality development strategy of training and upbringing.

The cognitive strategy is characteristic, first of all, of theories and concepts in which the main goal is the development of theoretical thinking and the scientific worldview formation. The theoretical knowledge priority is one of the leading teaching principles. Among the most wellknown Russian psychological and pedagogical theories related to this strategy include the learning activity theory (V. V. Davydov, D. B. Elkonin), the developing education theory (L. V. Zankov), the theory of problem-based teaching (M. I. Mahmutov, A. M. Matyushkin, etc.), the theory of the gradual formation of mental actions (P. Ya. Galperin).

The experiential strategy of education, training and upbringing is largely characteristic of theories and concepts in which the main goal is to form a subjective or personal experience for students. In modern Russian psychological and pedagogical theory and practice, the experiential strategy has, for the most part, found its place in the concepts of personality-oriented training and education (E. V. Bondarevskaya, A. A. Leontiev, V. V. Serikov, I. S. Yakimanskaya, etc.) Implementing the humanistic paradigm in education and upbringing, the developers of these concepts complement humanistic psychology with a dialectical-materialistic approach to understanding human essence.

The personality development strategy of training and education is characteristic of theories and concepts in which the goal is individual development from egocentrism to altruism. This strategy does not have a single methodological basis. Here it can be based on psychoanalytic theory (A. Freud, G. H. Green, W. Lay, O. Pfister, etc.), dialectical materialism (A. S. Makarenko, etc.), Christian metaphysics (V. V. Zenkovsky, etc.) and other worldview approaches. As a rule, in the theories and concepts of personality development strategy, the orientation of the individual understanding is considered so that the latter either overlaps the subjectivity of the person as a whole (Green, 1921; Makarenko, 1985; Pfister, 1923) or is considered as a spiritual hypostasis (Zenkovsky, 1996). Neither makes it possible to present human subjectivity in a differentiated way, distinguishing in the latter naturally-determined and spiritually-determined phenomena. We tried to present the most complete solution to this issue in the personalized learning concept (Kondratiev, 2010). In the framework of this concept, personalized learning is defined as a special type of training where the teacher, based on the knowledge of their typological characteristics and typical characteristics of students, organizes pedagogical interaction aimed at the intellectual, spiritual and moral development of students. In this case, there is a human subjectivity development as a form of reflexive and non-reflexive self-existence, which is manifested in the personality and the social individual of a person.

The starting point of personalized learning is: 
- it always involves the creation of such conditions for interaction between the teacher and students, when purposeful pedagogical influence is in demand by students, because it has social, personal and life significance for them;

- in personalized learning, the emphasis is not only on the individuality of students but also on the typical characteristics of the teacher and students, which affect the psychological content of their social individual;

- it is always aimed not only at the formation of the "subjective experience" of the student, but also at the intellectual, spiritual and moral development of their personality on the way from egocentrism to altruism and the formation of a social individual at the meta-ethnic level;

- the organization of personalized learning is carried out in collective forms, which ensure not only the personal growth of students from egocentrism to altruism, but also, to some extent solve, the problem of the ambivalence of the instinctive and reasonable in a person by establishing a compromise between the individual and the social individual.

The psychological compatibility of students and the teacher with students is a condition for personalized learning, and the basic psychological mechanism of personalized learning is an extraordinary pedagogical interaction (Kondratiev, 2010).

The intellectual development of students in personalized learning is represented as the mental experience formation. At the same time, special emphasis is placed on metacognitive intellectual representations inactivity. The result of such representations is a metacognitive experience as "mental structures that allow for involuntary regulation of processing information and arbitrary, conscious organization of their own intellectual activity" (Kholodnaya, 2019: 151). At the level of conscious intellectual activity, these are skills as readiness for activity (Milerjan, 1973; Chebysheva, 1983).

Metacognitive intellectual representations can be represented at two levels: competence and skill (L. A. Kartasheva, Yu.K. Kornilov, S. V. Kondratiev, M. A. Kholodnaya, I. Olri-Louis, etc.).

In modern educational psychology (based on cognitive psychology and built within the framework of humanistic or humanitarian paradigms), competence is usually understood as a special type of subject-specific knowledge organization that allows making effective decisions in the relevant field of activity (Kholodnaya, 2019).

The competence-based representative level is most comprehensively reflected in theoretical thinking and implemented in the theoretical preparation of the student for academic and work activities (Davydov, 1996).

Skill is a metacognitive intellectual representation in a specific practical activity, implementing interdisciplinary knowledge and skills to solve labour problems (Kondratiev, 2002). The most complete skill is shown in practical thinking. At its core, practical thinking is an integrative type of thinking. Based on theoretical thinking, practical thinking goes beyond the boundaries of individual sciences. It is always linked to the field, variety, etc., of labour and determines the intersubject meaningful various sciences integration in human practice.

As practice shows, high school students and students of professional education organizations show a fairly high level of practical thinking development based on the results of various educational and scientific competitions (Olimpiada.ru, n.d.). However, these are individual representatives of Russian youth. How systematic is it? As the analysis of the Russian 
Basic State Exam and Unified State Exam tasks shows, the emphasis is on the competence level of intellectual representations and the theoretical training of school graduates associated with (not only) activities. Results of the analysis of the orientation of (not only) school graduates also show their focus on educational activities (Oboyanskaya Secondary School № 2, n.d.).

This problem is largely due to the fact that there is not enough focus on building a joint activity of the teacher and students, depending on their psychological types. In this case, the typification of teachers and students should be based on the relationship between the characteristics of the individual and their activities. In this case, the intellectual development of students in the context of implementing metacognitive intellectual representations can be more effective.

Metacognitive intellectual representations in the personification of the educational environment in the conditions of society humanitarianization are necessary but insufficient. The spiritual and moral development of the individual on the way from egocentrism to altruism is fundamental. In this case, the theoretical and methodological basis is humanitarian psychology, including that built within the framework of the Christian paradigm (B. S. Bratus, A. A. Gostev, S. V. Kondratiev, J. C. Larchet, etc.). The development of personality, in this case, is connected with the development of reflection. The latter is understood as the process of self-knowledge of internal mental acts and states by the subject, the conversion of the human soul to itself (Karpikov, Kondratev, 2017: 62-64). Based on this, the development of personality is a dynamic process of reflection development along the path from egocentrism to altruism. However, in this development, there is a level of reflection development, when there is no differentiation of the subject and object in a person. In this case, the moral choice has not yet been made by a person. This personality level should be called infantile.

The infantile level of personality development is characterized by a low level of reflection. It is not always correlated with the ability to implement it. The inner world of a person often openly appears in the external being. At this level, the individual morality and moral norms begin to form, between which, as a rule, there are no contradictions.

Further development of the personality, its socialization, ensures the emergence of an egocentric level of personality development. Such a person, realizing themself as the central part of the world, enters into relations with others from a position of power: physical, mental, social, economic, political, etc. This level is characterized by synthetic reflection (Slobodchikov, Isaev, 1995: 203-204). Perceiving themself as the "centre of the world", a person seeks to dominate, impose their will when it is possible, and submit when it is impossible. The egocentric level can be represented in various forms: egoism, infantile egocentrism, authoritarian personality, internal personality (Karpikov, Kondratev, 2017: 74-80).

The highest level of personality development, from the position of Christian psychology, is the altruistic personality. Such a person can go beyond the boundaries their self, objectify and thus experience the highest spiritual feeling of love. Such a person enters into communication with other people, realizing their freedom as their own, hence there is humanism, goodwill, tolerance, generosity, etc. This person is always spiritually free and, therefore, can sacrifice themself and does it consciously out of love for their neighbour. The altruistic personality can also be represented by various forms: authoritarian altruism, humanistic altruism and theocentric altruism (Karpikov, Kondratev, 2017: 74-80).

To study the degree of spiritual and moral development of the individual in the educational environment in the direction from egocentrism to altruism, we conducted a study in the period from 2015 to 2018. Students of cadet corps, Suvorov military schools, Nakhimov naval schools, Cossack cadet corps, schools with cadet classes and schools with Cossack cadet classes were the object of the research. This choice was justified by the fact that in these educational organizations, the spiritual and moral development of the individual and patriotic education is the 
highest priority. More than 3,000 students took part in the study. As one of the methods, "Skazka Petushok" ["Fairytale Cockerel"] was used (Karpikov, Kondratev, 2017: 231-237). This projective technique diagnoses the personality development level: egocentric or altruistic. In it, personality is displayed through creative work - writing a fairytale on the topic. The text of the fairytale is processed using the content analysis method. The results are presented in Table 1.

Table 1.

Percentage distribution of the students of cadet corps, Suvorov military schools, Nakhimov naval schools, Cossack cadet corps, schools with cadet classes and schools with Cossack cadet classes of the tenth year of study by forms of personality development (2015-2018)

\begin{tabular}{ll}
\hline Forms of personality development & Control classes \\
\hline Egotism & 20 \\
\hline Infantile egocentrism & 15 \\
\hline Authoritarian egocentrism & 45 \\
\hline Internal egocentrism & 15 \\
\hline Authoritarian altruism & 5 \\
Humanistic altruism & 0 \\
\hline
\end{tabular}

The table shows that the student majority demonstrated authoritarian egocentrism. Also, a fairly large percentage of students showed egotism. The reason for this personality development level is probably not that there was still an insufficient level of work organization on spiritual and moral education (in these educational institutions, a lot of work is done on moral and patriotic education). The reason, most likely, is liberalism, which is actively introduced into public life and socialization of the individual in a post-industrial society.

\section{Conclusion}

The post-industrial society is characterized by liberal ideology. This ideology declares a personality cult, the dominance of values and interests of minorities, the erasure of national cultural characteristics, etc. In a post-industrial society, a person becomes a programmable component of the system. There is no place for such categories as spirituality, morality, citizenship and patriotism. Liberal ideology brings tension and instability and creates ethnic and social polarization in the Russian community. Among young people, including students, there is a lack of consistency in the issues of correct and constructive social behaviour, as well as the choice of life orientations. Therefore, today the issues of spiritual and moral development of the individual, for whom national interests, historically established cultural values, selfless service to the homeland and respect for the traditions of their population are important, become especially relevant. Opposition to liberal ideology should be based on a different ideology, the ideology of traditional morality, preserving national identity and spirituality of human existence. This is the ideology that should become the basis for the humanitarianization of post-industrial society, and this is the ideology that underlies personalized learning.

\section{References}

Bell, D. (1976). The cultural contradictions of capitalism. New York: Basic Books.

Chebysheva, V.V. (1983). Psihologija trudovogo obuchenija [Psychology of labour training]. Moscow: Vysshaja shkola.

Davydov, V.V. (1986). Problemy razvivajushhego obuchenija [Problems of developing learning]. Moscow: Pedagogika.

Davydov, V.V. (1996). Teorija razvivajushhego obuchenija [Theory of developmental learning]. Moscow: INTOR. 
Gostev, A.A. (2007). Psihologija vtorichnogo obraza [Secondary image psychology]. Moscow: Institut psihologii RAN.

Green, G.H. (1921). Psychoanalysis in the classroom. London: University of London Press.

Karpikov, A.A., Kondratev, S.V. (2017). Psihologija obuchenija i vospitanija: gumanitarnaja hristianskaja paradigma [Psychology of learning and education: a humanitarian Christian paradigm]. Moscow: INFRA-M.

Kholodnaya, M.A. (2019). Psihologija intellekta [Psychology of intelligence]. Paradoksy issledovanija. Moscow: Jurajt.

Kondratiev, S.V. (2002). Psihologija personificirovannogo obuchenija [Psychology of personalized learning]. Kaluga: KGPU im. K.Je. Ciolkovskogo.

Kondratiev, S.V. (2010). Integrativnaja subektnost cheloveka i obuchenie [Integrative human subjectivity and learning]. Moscow: Voshozhdenie.

Makarenko, A.S. (1985). Pedagogicheskie sochinenija [Pedagogical essays]. Moscow: Pedagogika.

Milerjan, E.K. (1973). Psihologija formirovanija obshhetrudovyh politehnicheskih umenij [Psychology of forming common-labour polytechnic skills]. Moscow: Pedagogika.

Oboyanskaya Secondary School № 2. Retrieved from: http://www.obo-sosh2.ru/

Olimpiada.ru, 1996-2020. Retrieved from: https://olimpiada.ru/

Pfister, O. (1923). The Psychoanalytic Method. London: Kegan Paul, Trench \& Trubner.

Rogers, C.R. (1969). Freedom to learn. Ohio: Charles E. Merril Publishing Company.

Slobodchikov, V.I., Isaev, E.I. (1995). Osnovy psihologicheskoj antropologii. Psihologija cheloveka: Vvedenie $\mathrm{v}$ psihologiju subektnosti [Fundamentals of psychological anthropology. Human psychology: Introduction to the psychology of subjectivity]. Moscow: Shkola Press.

Staroverova, M.S., Kovalev, E.V., Zaharova, A.V. (2014). Inkljuzivnoe obrazovanie. Nastolnaja kniga pedagoga, rabotajushhego s detmi s OVZ [Inclusive education. Table book of a teacher working with children with disabilities]. Moscow: Vlados.

Toffler, A. (1980). The Third Wave: The Classic Study of Tomorrow. New York: Bantam.

Zenkovsky, V.V. (1993). Problemy vospitanija v svete hristianskoj antropologii [Problems of education in the light of Christian anthropology]. Moscow: Izd-vo Svjato-Vladimirskogo bratstva.

Zenkovsky, V.V. (1996). Psihologija detstva [Psychology of the childhood]. Moscow: Akademija. 